\title{
Stable Isotope Evidence of Juvenile Foraging in Prehistoric Central California
}

\author{
Alexandra M. Greenwald ${ }^{1}$ \\ Jelmer W. Eerkens ${ }^{1}$
}

Eric J. Bartelink ${ }^{2}$

\footnotetext{
${ }^{1}$ Department of Anthropology, University of California, Davis

${ }^{2}$ Department of Anthropology, California State University, Chico
} 


\begin{abstract}
Ethnographic evidence demonstrates that hunter-gatherer children may forage effectively enough to supplement an adult provisioned diet, where ecology, subsistence strategies, and social organization are conducive to juvenile participation. We use stable isotope measures $(\delta 15 \mathrm{~N}$ and $\delta 13 \mathrm{C})$ from bone collagen and serial-samples of dentinal collagen extracted from first molars to examine childhood dietary patterns among 24 individuals from the Late Holocene Central California site CA-ALA-554. We identify weaning age and early childhood dietary patterns, and find evidence for independent child foraging among $25 \%$ of the sample population $(n=6)$, the majority of whom lived during the high-stress Medieval Climatic Anomaly (1100-700 BP).
\end{abstract}

Keywords: weaning, child foraging, stable nitrogen and carbon isotopes, hunter-gatherers, paleodiet 


\subsection{Introduction}

Modern Homo sapiens exhibit unique life history traits as compared to other mammals and primates, including a particularly helpless infancy period, relatively short lactation periods and interbirth intervals, and long childhoods (Dettwyler 2004; Hawkes et al. 1998; Hrdy 1999; Sellen 2006). A long period of somatic investment prior to sexual maturity reduces lifetime fertility, and it has been suggested that natural selection could favor delayed maturation and prolonged investment in growth if the costs of reduced fertility are outweighed by reduced mortality associated with a longer period of learning required for difficult or complex foraging tasks (Blurton Jones et al. 1994; Gurven and Kaplan 2006; Hawkes et al. 1998; Hrdy 1999; Kaplan et al. 2000).

Focus on child foraging behavior among ethnographic populations of hunter-gatherer groups has stemmed from attempts to test the embodied capital hypothesis to determine whether differences between food items taken by children and adults are a function of the correlation of learning and age, or of size and strength (Blurton Jones 2005; Dettwyler 2004; Hawkes et al. 1998; Hrdy 1999; Sellen 2006).

Ethnographic evidence demonstrates that hunter-gatherer children often supplement food provisioned by adults through foraging, at least when social organization, ecology, and subsistence strategies are conducive to juvenile participation (Bird and Bliege Bird 2000, 2002, 2005; Blurton Jones, et al. 1994). For example, in their comparison of !Kung and Hadza child foraging, Blurton Jones et al. (1994) note that local ecology has a significant impact on whether children forage. In easily navigated environments with food items accessible to children in proximity to a central place, children forage for resources that require little or no processing (Blurton Jones 2005; Blurton Jones et al.1994). Hadza children forage independently for berries and small game away from camp in small, mixed-cohort groups, and experience high enough return rates to supplement half of their daily caloric requirements (Blurton Jones et al. 1994; Crittenden et al 2013; Marlowe 2005). In contrast, !Kung children do not engage in any foraging activity, and are mostly or entirely dependent on adults for their subsistence needs. This has been attributed to the wide and patchy distribution of water and resources, paucity of shade, and the difficulty associated with navigating the Kalahari (Blurton Jones et al. 1994; Blurton Jones et al. 1989; Howell 2010; Marlowe 2005).

Tucker and Young (2005) similarly note the importance of environmental conditions in child foraging efficiency among the Mikea of Madagascar, where children's foraging contributes significantly to the household economy. The Mikea Forest offers an ideal environment for child foragers, with no predators and very few toxic plants. At age four or five, children begin harvesting wild tubers using strategies optimal for their strength and skill levels, as predicted by the marginal value theorem (Charnov 1976). Likewise, Bird and Bliege Bird have found that among the Martu and Meriam of Australia, size, as measured by height, is strongly correlated to foraging success, and that children make prey choice decisions that maximize their encounter rates and overall efficiency (Bird and Bliege Bird 2000, 2002, 2005; Bliege Bird and Bird 2002; Bliege Bird et al. 1995). Among the Meriam prey choices include shellfish, sessile resources that 
require minimal skill in procurement and processing, and among Martu small reptiles (Bird and Bliege Bird 2000, 2002, 2005; Bliege Bird and Bird 2002; Bliege Bird et al. 1995).

Although the Tsimane are not exclusively a foraging population, a systematic study conducted by Schniter et al. (2015) on the pre-reproductive skill acquisition of Tsimane children demonstrated that both boys and girls develop approximately $25 \%$ of their total lifetime food procurement skills by the age of ten, and that children beginning around age five are capable of supplementing their provisioned diet with food items they've procured.

As the ethnographic examples above illustrate, children may engage in foraging behavior that aids adult efforts and may even supplement their predominantly adult-provisioned diet. However, the resources that children pursue may not be included in the predicted diet breadth for adults. The diet breadth model, as originally conceived and applied in biology and human behavioral ecology, predicts the food items foragers will choose to exploit with the assumption that foragers are optimizing a currency (typically energy, or kilocalories) with direct fitness results (Charnov 1976; Kaplan and Hill 1992; MacArthur and Pianka 1966; Maynard Smith 1974; Schoener 1971). The model depicts foraging as divisible into two discrete, mutually exclusive components - search and handling time. The search time is the period devoted to looking for a food item, while handling time involves post-encounter pursuit, procurement, processing, and consumption of that food item (Bettinger 2009; Kaplan and Hill 1992). An optimal diet will incorporate food items that maximize energetic return per unit time of search and handling. A diet breadth model scaled to body size has demonstrated that child foragers conform to a predicted diet breadth that differs from adults as a result of the inclusion of resources that adults would likely ignore due to low return rates (Bird and Bliege Bird 2000, 2002, 2005; Bliege Bird and Bird 2002; Bliege Bird et al. 1995). The diet breadth model and its ethnographic applications suggest that children foraging independently will exploit a different suite of resources than adults, or incorporate a higher proportion of low-return foods into their diet than adults would.

While many species of mammals, including humans, learn and practice foraging skills through play-acting as juveniles (Harako 1980; Hewlett and Cavalli-Sforza 1986; Kamei 2005; Turnbull 1962), the degree to which children supplement their adult-provisioned diet may be used as a proxy for parental investment. Lower levels of parental provisioning due to an emphasis on somatic maintenance or sibling care would cause a reduction in the quality and/or quantity of foods provided by parents to their juvenile offspring.

\subsection{Child Foraging Patterns}

For the purposes of this study we delineate two primary types of child foraging behavior assistive and independent - based on the ethnographic observations of child foraging patterns summarized above. Assistive child foraging occurs when a child accompanies a parent or alloparent during their foraging activities and assists in a portion of the gathering or processing of the resource or resources being exploited. This may include, for example, a child helping to gather acorns with his or her mother. 
While unweaned infants and toddlers are typically carried by their mother on foraging trips to permit breastfeeding, weaned children can participate in assistive foraging by accompanying an adult, typically a parent of the same sex, during resource procurement activities. These children will therefore consume diets that are identical, either to the general adult population of their group, or identical to adult members of their sex within their group.

Independent child foraging observed ethnographically is defined by small, typically mixed agecohorts of children aged 5-9 foraging separately from adult food-getting activities, and in relatively close proximity to their group's settlement (Bird and Bliege Bird 2000, 2002, 2005; Bliege Bird and Bird 2002; Bliege Bird et al. 1995; Blurton Jones 2005; Blurton Jones et al. 1994; Crittenden et al. 2015). Children engaged in independent foraging will exploit foods that require no, or minimal, processing and that are typically not included in, or are a minor component of, an adult forager's diet breadth. Children supplementing their diets with foods foraged independently from adult foraging activities will consume a diet that differs slightly from that of adults within their group.

We seek to detect possible instances of childhood foraging behavior among a prehistoric foraging population in Central California by capitalizing on recent advancements in the archaeological application of stable isotope analysis to reconstruct the early childhood diet of 24 individuals from the Late Holocene archaeological site CA-ALA-554 (Figure 1), using collagen extracted from serial micro-samples of first molar dentin. Permanent first molars record information about dietary practices when an individual was an infant and child. As a result, serial section data permit the detection of dietary shifts in individuals while they were still children. This includes life history events such as weaning, post-weaning parental provisioning, and child foraging behavior.

\subsection{Archaeological Context}

Archaeological site CA-ALA-554 was excavated in 2011 by William Self and Associates (WSA), in what is now Pleasanton, California, within the ethnographic territory of the Ohlone peoples. At the time of prehistoric occupation, CA-ALA-554 was located along the southern shoreline of a freshwater marsh between two small watercourses within the California Coast Range. Excavations recovered 187 individuals from 165 burial features, as well as 24 non-burial features, including house floors, rock concentrations, and fire, or roasting pits (Estes et al. 2012).

Figure 1: Location of CA-ALA-554 in the Coast Range of Central California.

Although earlier periodic occupations date to the Middle Period (2160-940 BP), the site was continuously occupied year-round for approximately 600 years, from the MLT (940-740 years BP) into the Late Period 2 (440-180 BP), when it was abruptly abandoned. CA-ALA-554 experienced its largest spatial extent and highest population density during the Late Period 1 (740-440 BP) (Estes et al. 2012). Occupation of CA-ALA-554 is coincident with the Medieval Climatic Anomaly (MCA) (1100-700 BP), which is associated with episodic drought and 
increased climate variability in the region (Benson et al. 2002; Cook et al. 2004; Graumlich 1993; Stine 1994).

Because data recovery conducted by WSA at CA-ALA-554 was focused on burials and features in imminent threat of destruction from construction activities, floral and faunal materials are limited to those encountered in burial and feature matrices. Terrestrial fauna, with a high percentage of artiodactyl and leporid remains, dominate the site's faunal assemblage. Waterfowl and rodents are less abundant, but likely contributed to the prehistoric residents' diet. Very few fish and shellfish remains were recovered (Estes et al. 2012).

The archaeobotanical assemblage is dominated by acorn, including Quercus lobata, Q. kelloggii, and Q. agrifolia; and small seeds, including hairgrass (Deschampsia spp.), fescue (Vulpia spp.), clover (Trifolium spp.), farewell to spring (Clarkia spp.), red maids (Calandrinia spp.), and goosefoot (Chenopodium spp.). Flora found in lower concentrations that likely constituted a minor portion of the diet include geophytes (e.g. Brodiaea), bay (Umbellularia californica), buckeye (Aesculus californica), and hazel (Corylus cornuta var. californica), fiddleneck (Amsinckia spp.), saltbush (Atriplex spp.), brome grass (Bromus spp.), miners lettuce (Claytonia spp.), elderberry (Sambucus mexicana), tarweed (Madia spp.), maygrass (Phalaris spp.), and dock (Rumex spp.) (Estes et al. 2012).

The faunal and archaeobotanical evidence suggest a strong focus on the exploitation of terrestrial plants at CA-ALA-554, with terrestrial animal resources, as well as freshwater fish and waterfowl from the nearby watercourses and marsh constituting a minor portion of the diet (Estes et al. 2012). This evidence conforms to a larger regional pattern of Late Holocene resource intensification driven by increased population densities and the depletion of highranking resources, with an attendant diet breadth expansion in Central California (Broughton 1994; Groza 2002; Hildebrandt and Jones 2002; Hylkema 2002; Milliken et al. 2007; Wohlgemuth 1996, 2004). Also during the primary occupation period of CA-ALA-554, Milliken and Bennyhoff (1993) report a transition from high levels of wealth inequality, as measured by the quantity of Olivella shell beads interred in burials, to reduced levels of inequality and higher levels of average wealth.

\subsection{Archaeological Expectations}

We predict that the isotopic signature of a weaned child engaged in assistive foraging would closely resemble the adult average at the site. At sites with a significant difference in dietary signatures between men and women, children's diets reflect adult sex differences (Eerkens and Bartelink 2013). Unfortunately, the predicted isotopic signature of a child engaged in assistive foraging may not differ substantially from a child consuming a diet of adult-provisioned food, in which case the composition of their diet would also resemble the adult average at a site. For this reason, establishing clear evidence of assistive foraging separate from adult provisioning using stable isotopes is not possible with currently available methods. Due to this constraint, this paper will focus on the identification of independent child foraging. 
The diet of a prehistoric Central California child supplementing their diet with resources foraged independently of adult activities would vary with local ecology, as would the diets of the general population. At CA-ALA-554 and similar inland areas in Central California, independent child foragers would focus on sessile resources, especially additional plant foods requiring little or no processing (e.g. berries), freshwater shellfish, and possibly small reptiles. Therefore, we predict that a child's average trophic level would be lower compared to an adult's, resulting in an isotopic dietary signature that is depleted in ${ }^{15} \mathrm{~N}$ relative to ${ }^{14} \mathrm{~N}$ on the order of $0.5-1.5 \%$. By contrast, adult diets would include a higher percentage of terrestrial game resource that are higher on the trophic scale than plants.

\subsection{Methods}

Human biological tissues are generated from the food and water sources consumed by individuals. Within the macro- and micronutrients necessary for tissue synthesis, foods can vary in their stable isotope composition, including the ratio of ${ }^{13} \mathrm{C}$ to ${ }^{12} \mathrm{C}$ and ${ }^{15} \mathrm{~N}$ to ${ }^{14} \mathrm{~N}$. These elements, and their stable isotope ratios, are incorporated into tissues, though sometimes after internal fractionation, or enrichment of one isotope relative to the other. Collagen - the primary organic component of bone, dentin, and connective tissue - is synthesized primarily from dietary protein, and therefore contains stable isotopic signatures reflective of a large component of individuals' protein budget (Ambrose and Norr 1993; Tieszen and Fagre 1993; Schoeninger 1985; Schwarcz 2000).

Bone, which is approximately $27 \%$ collagen, is remodeled throughout an individual's life, with tissue turnover occurring every 10-20 years, depending on the skeletal element (Manolagas 2000; Hedges et al. 2007; White and Folkens 2005). Consequently, stable isotope measures derived from bone collagen inform on the dietary protein sources consumed during the individual's last decades of life (Eerkens and Bartelink 2013; Schwarcz and Schoeninger 1991). Unlike bone, teeth do not experience tissue turnover and replacement, although secondary dentin growth may occur in the pulp cavity during adulthood (Hillson 1986; White and Folkens $2005)$. Dentin, which is approximately $20 \%$ collagen, comprises the interior portion of the root and much of the tooth crown. Dentin accrues incrementally from the dentin-enamel junction (DEJ) in the crown to the apical root tip, with growth layers - similar to tree rings or sediment strata - accumulating at a predictable rate during tooth ontogeny (Hillson 1986; Hillson 1996) (Figure 2). Permanent first molars begin development at birth and complete root development at age eight to eleven (Gustafson and Koch 1974; Hillson 1986; Hillson 1996). Cutting small serial samples of first molars permits isotopic analysis of diet during small time intervals of an individual's childhood.

Figure 2: Diagram of molar anatomy depicting age-related landmarks (dentin enamel junction (DEJ) and cementum enamel junction (CEJ)), cross-section of the tooth, removal of the enamel, and serial micro-sections taken from the apical root tip to the DEJ.

Nitrogen isotope ratios, expressed as $\delta^{15} \mathrm{~N}$, display a trophic-level effect, wherein the collagen of a consumer will be enriched $2-4 \%$ o over the source of dietary protein (Schoeninger 1985; 
Schwarcz and Schoeninger 1991). This effect is preserved in the isotopes of serial samples in first molars. Thus, dentin from coronal sections, corresponding to breastfeeding infants, generally exhibit $\delta^{15} \mathrm{~N}$ variation at one trophic level above collagen from adult bone (Beaumont et al., 2013; Eerkens et al. 2011; Fuller et al. 2003; Fuller et al. 2006a; Fuller et al. 2006b). When a child is weaned and switches to solid foods $\delta^{15} \mathrm{~N}$ predictably drops, as measured in dentinal collagen (Eerkens et al. 2011; Fuller et al. 2003) (Figure 4). Post-weaning $\delta^{15} \mathrm{~N}$ indicate the approximate trophic level of dietary protein for an individual. In terrestrial environments, low $\delta^{15} \mathrm{~N}(6-8 \%$ ) indicates consumption of primarily plant-based proteins, while higher levels indicate incorporation of increased levels of animal-derived proteins (Figure 3).

Stable carbon isotopes in collagen weakly track trophic level, but show a stronger correlation with the biological or ecological source of dietary protein. In Central California, this measure most closely tracks marine versus terrestrial sources to the total protein budget (Figure 3). In coastal settings this permits the detection of fine-scaled changes in the consumption of shellfish, fish, and marine mammals. In interior regions, it more closely tracks the consumption of anadromous fish such salmon and sturgeon (Chisholm et al. 1982; Eerkens et al. 2011; Eerkens and Bartelink 2013; Fuller et al. 2006a, 2006b; Schoeninger and DeNiro 1984). Outside of California, $\delta^{13} \mathrm{C}$ may also be used as a reliable indicator of the dietary importance of $\mathrm{C}_{3}$ versus $\mathrm{C}_{4}$ plants, permitting archaeologists to trace the importance of $\mathrm{C}_{4}$ plants such as maize, sorghum, and millet, or animals who foddered on these plants, in the diet (Schoeninger 2009). However, in Central California, $\mathrm{C}_{4}$ plants may be ruled-out as a source of protein because these plants are uncommon and did not play an important role in the subsistence economy of local hunter-gatherers.

Figure 3: Plot of economically important food resources of Central California in collagen isotopic space. $\delta^{13} \mathrm{C}$ values are on the $\mathrm{x}$-axis and $\delta^{15} \mathrm{~N}$ values are on the $\mathrm{y}$-axis. Isotopic values based on Bartelink (2006).

\subsection{Samples}

Well-preserved first molars, as well as bone samples of fibulae, ulnae, and radii, were obtained by the authors from ancestral Ohlone burials excavated by William Self and Associates at CAALA-554 (Table 1). Ramona Garibay, the legally appointed Most Likely Descendant (MLD) for the Ohlone/Costanoan tribe, granted permission for the research. Radiocarbon dates show that the cemetery component of the site was used primarily during the Middle (2160-940 years BP), Middle-Late Transition (MLT) (940-740 years BP), and Late (740-180 BP) Periods (Table 1).

\subsubsection{Sampling Methods}

Prior to sampling, burials were cataloged, photographed and/or drawn, and bioarchaeological and osteometric analyses conducted to estimate stature, sex, and age at death, and record existing pathological conditions. Extracted teeth were photographed, and cut in half with a slow-speed diamond saw to focus isotopic analyses on one crown-root sequence. Following our recently-developed methods previously described in Eerkens et al. (2011), enamel and cementum, as well as secondary dentin growth, were removed from one half of the molar with a drill equipped with a tungsten carbide bit. Teeth were demineralized in 0.5 molar hydrochloric 
acid $(\mathrm{HCl})$ at $5^{\circ} \mathrm{C}$, and humic contaminants removed with 0.125 molar sodium hydroxide $(\mathrm{NaOH})$. The cortical component of bone samples was isolated and cleaned, and subjected to the same chemical processing as teeth described above.

Table 1: Twenty-four individuals sampled from the CA-ALA-554 burial population for the present study. The sample includes 7 females, 8 males, and 9 juveniles of indeterminate sex. AMS dating done by Eckert \& Ziegler Vitalea Science using collagen samples prepared by the primary author. Dates calibrated using Calib 7.1 with the IntCal13 calibration curve. Calibrated dates listed are the median from probability distribution including all intercepts. The $1-\sigma$ range presented is the minimum and maximum age for all $1-\sigma$ intercepts.

After demineralization, teeth were sliced into 10-20 $1 \mathrm{~mm}$-thick serial sections (micro-samples), controlling for age-related landmarks (dentino-enamel junction (DEJ), cervico-enamel junctions (CEJ), and apical root tip) that permit internal aging of the tooth (see Figure 1). Collagen was extracted and freeze-dried from the bone samples and each serial section of first molars, and $1 \mathrm{mg}$ from each serial section and bone sample analyzed for $\delta^{15} \mathrm{~N}$ and $\delta^{13} \mathrm{C}$ on a PDZ Europa ANCA-GSL elemental analyzer interfaced to a PDZ Europa 20-20 light isotope ratio mass spectrometer (IRMS) at the UC Davis Department of Plant Science Stable Isotope Facility (SIF).

\subsection{Analysis}

First molars grow at a rate of approximately $1.8 \mathrm{~mm}$ per year in the crown and $1.7 \mathrm{~mm}$ per year in the root, and the CEJ of the first molar is formed around age 2.75 years (Hillson, 1996; Dean and Vesey, 2008; Dean et al., 1993). Age at weaning is estimated by examining $\delta^{15} \mathrm{~N}$ (measured in permil) in each serial sections and looking for a $2-4 \%$ drop in $\delta^{15} \mathrm{~N}$ associated with a onetrophic-level difference in diet, from breastmilk to solid food. Age of weaning can be tied to an individual's biological age on the scale of months based on the location of the $\delta^{15} \mathrm{~N}$ shift relative to the DEJ, CEJ, and apical root tip and growth rates. Estimations of post weaning diet relies on both $\delta^{15} \mathrm{~N}$, related to trophic level, and $\delta^{13} \mathrm{C}$, which indicates the degree to which dietary protein is derived from marine versus terrestrial environments.

\subsection{Results}

We address isotopic evidence of life-history landmarks in chronological order, beginning with age at weaning, followed by post-weaning diet, and concluding with evidence of independent foraging in middle childhood.

First molar isotopic data for all 24 sampled individuals are presented in the appendix. The Sample ID indicates the burial number, while the lower case letter indicates the serial sample within the tooth. Serial samples start at "a" at the apical root tip, and proceed alphabetically to the crown at or near the DEJ, typically in the range of "I" through "o". Because teeth begin growth at the crown and grow apically to the root tip, samples early in the alphabet indicate diet later in tooth formation (ages 7-9 in first molars), while samples falling in the middle of the alphabet indicate diet earlier in tooth formation (ages 0-4 in first molars). In cases where collagen yield was low, serial samples were combined to reach the necessary minimum of $1 \mathrm{mg}$ per sample for isotopic analysis. 


\subsection{Age at Weaning}

All sampled individuals, with the exception of a juvenile (burial 165) and an adult male (burial 128), show the predicted elevated $\delta^{15} \mathrm{~N}$ in the crown samples, close to the DEJ, indicative of high trophic level protein in the earliest stages of life. This is consistent with an infant obtaining all of its protein from its mother through breastmilk. The high $\delta^{15} \mathrm{~N}$ is then followed by a noticeable drop across serial micro-samples. This drop is between 2 and 4\%, consistent with a full drop in trophic level, as expected when an infant transitions from breastmilk to solid food. However, as the weaning curves in Figure 4 demonstrate, the weaning process, or the period of time during which a mother transitions her child from breastmilk to solid foods, varies between individuals. A steep curve indicates an abrupt transition, whereas a lengthier, more gradual curve indicates a more prolonged weaning process.

The graphs in Figure 4 plot the serial samples of $\delta^{15} \mathrm{~N}$ and $\delta^{13} \mathrm{C}$ for a subsample of the 24 individuals sampled. Each chart represents a single tooth, with $\delta^{15} \mathrm{~N}$ plotted on the primary $\mathrm{y}$ axis, and $\delta^{13} \mathrm{C}$ plotted on the secondary $\mathrm{y}$-axis. Each point within a chart represents a serial sample. The corresponding average age for each serial sample is plotted on the $x$-axis. The left side of each chart shows sections from within the crown, while the right side shows samples from the root tip.

Figure 4: The charts above depict $\delta^{15} \mathrm{~N}$ and $\delta^{13} \mathrm{C}$ in first molar serial samples for 6 individuals of the 24 included in the study. After a 2-4\%o drop in $\delta^{15} \mathrm{~N}$ associated with weaning (typically between 1.5 and 3.5 years of age), children consume a diet that tracks the adult $\delta^{15} \mathrm{~N}$ average at the site (8.26\%). Between the ages of 5 and 9 , approximately a third of individuals exhibit a $0.75-1.5 \%$ odrop in $\delta^{15} \mathrm{~N}$. This isotopic signature indicates that many children are consuming diets in middle childhood that deviate from the diets of weaned infants and adults (see section 3.3).

Table 2 lists the period of exclusive breastfeeding, the duration of the weaning process, and the age at weaning (AAW) in months for the 24 individuals sampled from the burial population. The average age at full completion of weaning is approximately 28 months, or 2.3 years of age. There are several notable outliers, including two females who were weaned at the ages of 4 (burial 1) and 4.4 years (burial 157), and one male who was weaned at 8 months (burial 115), and another weaned at 3.25 years (burial 45 ).

Table 2: Duration of exclusive breastfeeding and the weaning process, and age at weaning (AAW) in months, and post-weaning $\delta^{15} \mathrm{~N}$ values for the 24 burials sampled.

While the individuals who experienced very early or very late weaning exhibit breastfeeding and weaning period durations that generally scale to their age at weaning, the majority of individuals are exclusively breastfed for 6 to 18 months and experience a weaning process lasting an additional 14 to 20 months prior to complete cessation of breastfeeding.

\subsection{Post-weaning Diet}

Children's diets immediately post-weaning are isotopically very similar to those of adults; weanlings exhibit an average $\delta^{15} \mathrm{~N}$ signature of $8.04 \%$, while adults at the site average $8.26 \%$ (Table 2 and Figure 5). Individuals fall within the same trophic level as adults $\left(\delta^{15} \mathrm{~N}\right.$ is within 
$1.5 \%$ o), and appear to be deriving their dietary protein from the same sources $\left(<1.5 \%\right.$ o $\delta^{13} \mathrm{C}$ variation). This data indicates that weanlings are accessing the same sources of dietary protein as adults, which is most likely a result of parents and alloparents provisioning weaned children with a diet nearly identical to their own. The slightly lower average $\delta^{15} \mathrm{~N}$ values $(\sim 0.22 \%$ o for weanlings relative to adults is likely a result of young children having some difficulty consuming higher trophic level foods eaten with ease by adults. Ethnographic evidence from Central California suggests that weanlings often consumed gruels or mush primarily composed of plants (acorns or small seeds) augmented with pounded terrestrial, aquatic, or marine protein (Harrington 1942; Kroeber 1925).

Figure 5: Adult versus weanling values. Individuals who died as juveniles are not included in this comparison. The difference between adult and early childhood diet immediately post-weaning is plotted for $\delta^{15} \mathrm{~N}$ above the horizontal axis and for $\delta^{13} \mathrm{C}$. Burials are on the horizontal axis. The closer a weanling data point (solid triangle) is to the center of the adult data point (open circle), the more similar the diets were. Individuals that fall at the center consumed an early childhood diet nearly identical to their adult diet.

\subsection{Independent Foraging}

After a period of exclusive post-weaning parental provisioning, during which adult and child diets resemble one and other, $25 \%$ of individuals $(n=6)$ show a marked drop in $\delta^{15} \mathrm{~N}$ signatures on the order of $0.75-1.5 \%$ o during ages 5 to 9 (see Figure $4 b, c$, f and Figure 6). This indicates that over the period of several years in middle childhood, these individuals were consuming resources that differed from the average adult diet at CA-ALA-554, as well as from their own post-weaning diet. The reduced enrichment in $\delta^{15} \mathrm{~N}$ suggests that, as children, these 6 individuals consumed lower trophic level foods, perhaps plants that required minimal processing, and possibly small vertebrates, that supplemented adult-provisioned foods.

A two-tailed t-test indicates that there is no statistically significant difference between the average age at death for these six individuals ( 22.5 years) versus the total sample size of individuals ( 22.9 years), and neither is there a significant difference between the average age at weaning ( 25.2 months versus 26.8 months). The independent foraging signal is present in at least one male and two females, however, the sample size of individuals exhibiting this independent foraging signal is too small to draw meaningful conclusions regarding sex-based differences.

Four of the six individuals with an independent foraging signal date to the Middle Period (2160940 years BP) and two to the Late Period (740-180 BP); four of the six individuals fall within the time period associated with the Medieval Climatic Anomaly (MCA) (1100-700 BP).

\subsection{Discussion and Conclusions}

We have found possible evidence that some individuals at the Central California site CA-ALA554 engaged in independent foraging efforts as children. These individuals show a $0.75-1.5 \%$ o drop in $\delta^{15} \mathrm{~N}$ signatures during the ages of 5 to 9 commensurate with consuming a diet that is proportionally higher in lower-trophic level foods than the average adult at the site. The age range during which this independent foraging signal occurs among the individuals at CA-ALA- 
554 is consistent with cross-cultural ethnographic observations of child foraging behavior, as is the increased focus on lower-ranking resources, as compared to adults, that previous dietbreadth models for children have predicted (Bird and Bliege Bird 2000, 2002, 2005; Bliege Bird and Bird 2002; Bliege Bird et al. 1995). However, unlike the previously referenced ethnographic accounts of independent child foraging in which most children participate, we find isotopic signatures of independent foraging in only $25 \%$ of our sample.

There were likely many social and ecological factors that affected the costs and benefits of independent child foraging to both children and adults in prehistoric Central California, and therefore impacted the likelihood that individuals would engage in independent foraging. These factors include environmental risk, resource availability, and accumulation of wealth.

Ethnographic evidence suggests that children engaged in independent foraging pursue resources that require minimal or no processing, like fruit, insects, shellfish, and small mammals. For adults, these food items may be outside the diet breadth due to the small size and low returns, but a diet breadth model scaled to a child's body size would predict inclusion in the child forager's diet (Bird and Bliege Bird 2000, 2002, 2005; Bliege Bird and Bird 2002; Bliege Bird et al. 1995). The presence of these resources in the environment in close proximity to a habitation site would permit independent child foraging.

The accumulation of wealth, in the form of stored foods and bead wealth, likely impacted child foraging behavior in two ways. Children in wealthier families would have had improved access to food, potentially lowering their likelihood of engaging in independent foraging activities. Conversely, increased concentration of wealth, and therefore increased inequality, would correlate with higher rates of independent child foraging among non-wealthy families.

Environmental risks to children engaged in independent foraging included predators, difficultto-navigate terrain, and violence. In environments where these risks are high, the potential costs of children engaging in unsupervised or minimally supervised activities may have been prohibitively high to children themselves, as well as their parents.

The primary occupation period at CA-ALA-554 overlaps with the Medieval Climatic Anomaly (MCA) (1100-700 BP), and many of the individuals in our sample lived during this time. A majority of the individuals exhibiting an independent foraging signal lived during the MCA (Figure 6).

The archaeological correlates of the MCA across California have been identified as disruptions in exchange systems (Arnold 1992; Gilreath and Hildebrandt 1997; Jones et al. 1999), subsistence shifts (Collins 2010; Kennett and Kennett 2000), altered settlement patterns (Gardner 2006; Hull 2007; Jones and Ferneau 2002), and higher levels of disease, undernutrition, and violence (Andrushko et al. 2010; Jones and Schwitalla 2008; Lambert 1994, 1997; Pilloud et al. 2014; Raab and Larson 1997; Schwitalla 2013; Schwitalla and Jones 2012). 
Recent work has used the Central California Bioarchaeological Database (CCBD) to assess the impacts of the MCA on rates of nutritional stress, disease, and interpersonal violence in Central California regions, including the San Francisco Bay Area, Delta, and Central Valley (Jones and Schwitalla 2008; Pilloud 2006; Pilloud et al. 2014; Schwitalla 2013; Schwitalla and Jones 2012). These studies found higher frequencies of skeletal pathologies like cribra orbitalia, porotic hyperostosis, and enamel hypoplasia attributable to disease and malnutrition, in addition to increased rates of pre- and peri-mortem sharp and blunt force trauma indicative of violence, during the MCA. Increased rates of disease, malnutrition, and violence during the MCA have been attributed to drought-related subsistence short-falls and associated competition for resources (Jones and Schwitalla 2008; Lambert 1994, 1997; Pilloud et al. 2014; Schwitalla 2013; Schwitalla and Jones 2012).

At CA-ALA-554, MCA-related stress is reflected in higher mortality rates across all age groups, though the effect is most pronounced in infants, juveniles, and women aged 19 to 25 (Schwitalla 2013; Estes et al. 2012). Additionally, there is evidence of increased rates of interpersonal violence at CA-ALA-554 associated with the MCA, including a mass grave of males exhibiting evidence of perimortem sharp- and blunt-force trauma (Eerkens et al. 2015).

Figure 6: Distribution of burials at CA-ALA-554 with and without independent foraging signal across time. A higher proportion of those with an independent foraging signal fall within the MCA than those individuals who do not exhibit the signal.

We suggest that the MCA stimulated the incentives for parents and children to pursue independent child foraging, as any efforts by children to supplement their parentallyprovisioned diet would have aided the already stressed household subsistence economy and permitted parents to focus their most intensive investment in younger and more vulnerable offspring.

In spite of increased levels of interpersonal violence associated with resource scarcity and territorial circumscription and risks associated with unsupervised foraging (e.g., rattlesnakes, falls), the value of independent foraging activities to families during difficult years may have promoted this activity. In particular, we note that four of eight individuals who lived during the MCA (50\%) seem to have engaged in independent foraging, while only two of ten (20\%) who lived either before or after the MCA did. The sample size is certainly small, but we suggest that difficulty gaining food and/or increased uncertainty in foraging during especially difficult years within the MCA caused an increasing number of individuals to pursue independent childhood foraging.

Acknowledgments: This study would have been impossible without the permission and support provided by Ohlone tribal representative and designated Most Likely Descendant (MLD) Ramona Garibay. Special thanks to Doug Bird, Bruce Winterhalder, and Monique Borgerhoff Mulder for their guidance and feedback. Thank you to Gregory R. Burns for support, feedback, and help creating figures 1 and 3; Kelly Eldridge for her help creating figure 2; and to undergraduate laboratory assistants Marcos Martinez, Kamil Rochon, Eden Washburn, Tina Murray, A. Gracie Viera, and J. Virangika Perera. The development of this paper owes much to the feedback and questions 
from the attendees of the 2014 California Workshop on Evolutionary Social Sciences and the 2014 meeting of the Western Bioarchaeology Group. This research was made possible with grants from the UC Davis Department of Anthropology to A.M. Greenwald and the National Science Foundation (BCS-1318532) to J.W. Eerkens and E.J. Bartelink.

\subsection{References Cited}

Ambrose SH, Norr L. 1993. Experimental evidence for the relationship of the carbon isotope ratios of whole diet and dietary protein to those of bone collagen and carbonate. In: Lambert JB, Grupe G, editors. Prehistoric human bone: archaeology at the molecular level. New York: Springer-Verlag. p 1-37.

Andrushko, Valerie A., Kate A. S. Latham, Diane L. Grady, Allen G. Pastron, and Phillip L. Walker. 2005. Bioarchaeological evidence for trophy-taking in prehistoric central California. American Journal of Physical Anthropology 127:375-384.

Arnold, J.E. 1992. Complex Hunter-Gatherer-Fishers of Prehistoric California: Chiefs, Specialists, and Maritime Adaptations of the Channel Islands. American Antiquity 57:60-84.

Bartelink, Eric J. 2006. Resource intensification in pre-contact central California: a bioarchaeological perspective on diet and health patterns among hunter-gatherers from the lower Sacramento Valley and San Francisco Bay. Doctoral dissertation, Texas A\&M University, College Station, TX. University Microfilms, Ann Arbor, Michigan.

Benson, L., Kashgarian, M., Rye, R., Lund, S., Paillet, F., Smoot, J., Kester, C., Mensing, S., Meko, D. and Lindström, S. 2002. Holocene multidecadal and multicentennial droughts affecting Northern California and Nevada. Quaternary Science Reviews, 21(4):659-682.

Bettinger, R.L. 2009. Hunter-Gatherer Foraging: Five Simple Models. Eliot Werner Publications, Inc., Clinton Corners, New York.

Bird, D.W. and R. Bliege Bird. 2000. The ethnoarchaeology of juvenile foraging. Journal of Anthropological Archaeology 19:461-467.

Bird, D.W. and R. Bliege Bird. 2002. Children on the reef: Slow learning or strategic foraging? Human Nature 13:269-298.

Bird, D.W. and R. Bliege Bird. 2005. Martu Children's Hunting Strategies in the Western Desert, Australia. In Hunter-Gatherer Childhoods, eds. B.S. Hewlett and M.E. Lamb. AldineTransaction, New Brunswick, New Jersey.

Bliege Bird, R. and D.W. Bird. 2002. Constraints of knowing or constraints of growing? Fishing and collecting among the children of Mer. Human Nature 13:239-268.

Bliege Bird, R., D.W. Bird, and J.M. Beaton. 1995. Children and tradition subsistence on Mer (Murray Island), Torres Strait, Australia. Australian Aboriginal Studies 1995:2-17.

Blurton Jones, N. 2005. Introduction. In Hunter-Gatherer Childhoods, eds. B.S. Hewlett and M.E. Lamb. AldineTransaction, New Brunswick, New Jersey.

Blurton Jones, N., K. Hawkes, and J.F. O'Connell. 1989. Modeling and measuring costs of children in two foraging societies. In Comparative socioecology. V. Standen and R. Foley, eds. Blackwell, Oxford. 
Blurton Jones, N. and F. Marlowe. 2002. Selection for delayed maturity: Does it take 20 years to learn to hunt and gather? Human Nature 13:199-238.

Blurton Jones, N., K. Hawkes, and P. Draper. 1994. Differences Between Hadza and !Kung Children's Work: Affluence or Practical Reason? In Key Issues in Hunter-Gatherer Research, eds. E.S. Burch, Jr. and L.J. Ellanna. Burg Publishers, Providence, Rhode Island.

Bock, John. 2005. What Makes a Competent Adult Forager? In Hunter-Gatherer Childhoods, eds. B.S. Hewlett and M.E. Lamb. AldineTransaction, New Brunswick, New Jersey.

Borgerhoff Mulder, Monique. 1992. Reproductive Decisions. In Evolutionary Ecology and Human Behavior. E.A. Smith and B. Winterhalder, eds. Pg. 339-374. Aldine de Gruyter, New York, NY.

Broughton, J.M. 1994a. Declines in Mammalian Foraging Efficiency During the Late Holocene, San Francisco Bay, California. Journal of Anthropological Archaeology 13:371-401.

Broughton, J.M. 1994b. Late Holocene Resource Intensification in the Sacramento Valley, California: The Vertebrate Evidence. Journal of Archaeological Science 21:501-514.

Broughton, J.M. 2004. Declines in Mammalian Foraging Efficiency During the Late Holocene, San Francisco Bay. In Prehistoric California: Archaeology and the Myth of Paradise, edited By L.M. Raab and T.L. Jones, pp. 34-52. University of Utah Press, Salt Lake City.

Charnov, E.L. 1976. Optimal foraging: the marginal value theorem. Theoretical Population Biology 9:129-136.

Chisholm, B.S., D.E. Nelson and H.P. Schwarcz. 1982. Stable carbon isotope ratios as a measure of marine versus terrestrial protein in ancient diets. Science 216:1131-1132.

Codding, B.F., R. Bliege Bird, and D.W. Bird. 2011. Provisioning offspring and others: risk-energy trade-offs and gender differences in hunter-gatherer foraging strategies. Proceedings of the Royal Society B 278:2502-2509.

Collins, G.E. 2010. Bone Fragmentation as an Indicator of Subsistence Stress in the North Coast Ranges of California. Unpublished Masters thesis, Department of Anthropology, California State University, Chico.

Cook, E.R., Woodhouse, C.A., Eakin, C.M., Meko, D.M. and Stahle, D.W. 2004. Long-term aridity changes in the western United States. Science, 306(5698):1015-1018.

Crittenden, A.N., N.L. Conklin-Brittain, D.A. Zes, M.J. Schoeninger, and F.W. Marlowe. 2013. Juvenile foraging among the Hadza: Implications for human life history. Evolution and Human Behavior 34:299-304.

Dean MC, Beynon AD, Reid DJ, Whittaker DK. 1993. A longitudinal study of tooth growth in a single individual based on long- and short-period incremental markings in dentine and enamel. Int J Osteoarchaeol 3:249-264.

Dean MC, Vesey P. 2008. Preliminary observations on increasing root length during the eruptive phase of tooth development in modern humans and great apes. J Hum Evol 54:258-271.

Dettwyler KA. 2004. When to wean: biological versus cultural perspectives. Clin Obstet Gynecol 47:712-723.

Eerkens, J.W. and E.J. Bartelink. 2013. Sex-biased weaning and early childhood diet among Middle Holocene hunter-gatherers in Central California. Am J Phys Anth 152:471-483.

Eerkens, J.W., A.G. Berget, and E.J. Bartelink. 2011. Estimating weaning and early childhood diet from serial microsamples of dentin collagen. Journal of Archaeological Science 38:3101-3111. 
Estes, A., M.A. Medieros, and J. Allen. 2012. Report on Archaeological Data Recovery at CA-ALA-554, Pleasanton, California, Volume II: Human Osteology. William Self Associates, Orinda, California.

Fuller, B.T., J.L. Fuller, D.A. Harris, and R.E.M. Hedges. 2006a. Detection of Breastfeeding and Weaning in Modern Human Infants with Carbon and Nitrogen Stable Isotope Ratios. American Journal of Physical Anthropology 129: 279-293.

Fuller BT, Molleson TI, Harris DA. Gilmour LT, Hedges REM. 2006b. Isotopic evidence for breastfeeding and possible adult dietary differences from late/sub-Roman Britain. Am J Phys Anthropol 129:45-54.

Fuller, B.T., M.P. Richards, S.A. Mays. 2003. Stable carbon and nitrogen isotope variations in tooth dentine serial sections from Wharram Percy. Journal of Archaeological Science 30: 1673-1684.

Gardner, J.K. 2006. The Potential Impact of the Medieval Climatic Anomaly on Human Populations in the Western Mojave Desert. Unpublished Ph.D. dissertation, Department of Anthropology, University of Nevada, Las Vegas.

Gilreath, A.J. and W.R. Hildebrandt. 1997. Prehistoric Use of the Coso Volcanic Field. Contributions of the University of California Archaeological Research Facility No. 56, Berkeley.

Graumlich, L.J. 1993. A 1000-year record of temperature and precipitation in the Sierra Nevada. Quaternary Research 39:249-255.

Groza, R. 2002. An AMS Chronology for Central California Olivella Shell Beads. Masters' thesis, Department of Anthropology, California State University, San Francisco, San Francisco.

Gurven, M. and H. Kaplan. 2006. Determinants of time allocation across the lifespan. Human Nature 17:1-49.

Gustafson, G. and G. Koch. 1974. Age estimation up to 16 years of age based on dental development. Odontological Rev 25:297-306.

Harako, R. 1980. Growth and play in a hunter-gatherer society. Collection of papers of college and liberal arts, Meiji University. 137:1-44.

Harrington, John P. 1942. Culture Element Distributions: XIX Central California Coast. Anthropological Records 7:1, University of California Press, Berkeley and Los Angeles.

Hawkes, K., J.F. O'Connell, and N. Blurton Jones. 1991. Hunting income patterns among the Hadza: big game, common goods, foraging goals and the evolution of the human diet. Philosophical Transactions of the Royal Society of London B 334:243-251.

Hawkes, K., J.F. O'Connell, and N. Blurton Jones. 1995. Hadza children's foraging: Juvenile dependency, social arrangements and mobility among hunter-gatherers. Current Anthropology 36:688-700.

Hawkes, K., J.F. O'Connell, and N. Blurton Jones. 1997. Hadza women's time allocation, offspring provisioning, and the evolution of long postmenopausal life spans. Current Anthropology 38:551-577.

Hawkes, K., J.F. O'Connell, N.G. Blurton Jones, H. Alvarez, and E.L. Charnov. 1998. Grandmothering, menopause, and the evolution of human life histories. PNAS 95:1336-1339.

Hedges REM, Clement JG, Thomas CDL, O'Connell TC. 2007. Collagen turnover in the adult femoral mid-shaft: modeled from anthropogenic radiocarbon tracer measurements. Am J Phys Anthropol 133:808-816. 
Hewlett, B.S. and L.L. Cavalli-Sforza. 1986. Cultural transmission among the Aka Pygmies. American Anthropologist 88:922-934.

Hildebrandt, W.R. and T.L. Jones. 2002. Depletion of Prehistoric Pinniped Populations Along the California and Oregon Coasts: Were Humans the Cause? In Wilderness and Political Ecology: Aboriginal Influences and the Original State of Nature, edited by C.E. Kay and R.T. Simmons, pp. 72-110. University of Utah Press, Salt Lake City.

Hillson, S. 1986. Teeth. Cambridge: Cambridge University Press.

Hillson S. 1996. Dental anthropology. Cambridge: Cambridge University Press.

Howell, N. 2010. Life Histories of the Dobe !Kung: Food, Fatness, and Well-Being Over the Life-Span. University of California Press, Berkeley.

Hrdy, Sarah B. 1999. Mother Nature: A History of Mothers, Infants and Natural Selection. Pantheon, New York.

Hull, K. 2007. The Sierra Nevada: Archaeology in the Range of Light. In California Prehistory: Colonization, Culture, and Complexity, edited by T.L. Jones and K.A. Klar, pp. 177-190. AltaMira Press, Lanham, Maryland.

Hylkema, M.G. 2002. Tidal Marsh, Oak Woodlands, and Cultural Florescence in Southern San Francisco Bay Region. In Catalysts to Complexity: Late Holocene Societies of the California Coast, edited by J.M. Erlandson and T.L. Jones, pp. 233-262. Cotsen Institute of Archaeology, University of California, Los Angeles.

Jones, T.L., G. Brown, L.M. Raab, J. McVickar, G. Spaulding, D.J. Kennett, A. York, and P.L. Walker. 1999. Environmental Imperatives Reconsidered: Demographic Crises in Western North America during the Medieval Climatic Anomaly. Current Anthropology 40:137-156.

Jones, T.L. and J.A. Ferneau. 2002. Deintensification along the central coast. In Catalysts to Complexity: Late Holocene Societies of the California Coast, edited by J.M. Erlandson and T.L. Jones, pp. 205-232. Cotsen Institute of Archaeology, University of California, Los Angeles.

Jones, T. L., Schwitalla, A. 2008. Archaeological perspectives on the effects of medieval drought in prehistoric California. Quaternary International 188:41-58.

Kamei, N. 2005. Play among Baka Children in Cameroon. In Hunter-gatherer childhoods: evolutionary, developmental and cultural perspectives, ed. B.S. Hewlett and M.E. Lamb, pp. 343-359. Aldine Transaction, New Brunswick.

Kaplan, H. and K. Hill. 1992. The Evolutionary Ecology of Food Acquisition. In Evolutionary Ecology and Human Behavior. E.A. Smith and B. Winterhalder, eds. Pg. 167-201. Aldine de Gruyter, New York, NY.

Kaplan, H., K. Hill, J. Lancaster, and M. Hurtado. 2000. A theory of human life history evolution: diet, intelligence, and longevity. Evolutionary Anthropology 9:156-185.

Kellner C, Schoeninger MJ. 2007. A simple carbon isotope model for reconstructing prehistoric human diet. Am J Phys Anthropol 133:1112-1127.

Kennett, D.J. and J.P. Kennett. 2000. Competitive and Cooperative Responses to Climatic Instability in Coastal Southern California. American Antiquity 65(2):379-395.

Kroeber, A.L. 1925. Handbook of the Indians of California. Dover Publications, Inc., New York. 
Lambert, P.M. 1994. War and Peace on the Western Front: A Study of Violent Conflict and its Correlates in Prehistoric Hunter-Gatherer Societies of Coastal California. Unpublished Ph.D. dissertation, Department of Anthropology, University of California, Santa Barbara.

Lambert, P.M. 1997. Patterns of Violence in Prehistoric Hunter-Gatherer Societies of Coastal Southern California. In Troubled Times: Violence and Warfare in the Past, eds. D.L. Martin and D.W. Frayer, pp. 77-110. Routledge, New York.

MacArthur, E.H. and E.R. Pianka. 1966. On optimal use of a patchy environment. American Naturalist 100:603-609.

Manolagas S. 2000. Birth and death of bone cells: basic regulatory mechanisms and implications for the pathogenesis and treatment of osteoporosis. Endocr Rev 21:115-137.

Marlowe, F.W. 2005. Who Tends Hadza Children? In Hunter-Gatherer Childhoods, eds. B.S. Hewlett and M.E. Lamb. AldineTransaction, New Brunswick, New Jersey.

Maynard Smith, J. 1976. Models in Ecology. Cambridge University Press, Cambridge.

Milliken, R.T. and J.A. Bennyhoff. 1993. Temporal Changes in Beads as Prehistoric California Grave Goods. In There Grows a Green Tree: Papers in Honor of David A. Fredrickson, eds. G. White, P. Mikkelsen, W.R. Hildebrandt, and M.E. Basgall, pp. 381-395. Center for Archaeological Research at Davis, volume 11. University of California, Davis.

Milliken, R., R.T. Fitzgerald, M.G. Hylkema, R. Groza, T. Origer, D. G. Bieling, A. Leventhal, R. Wiberg, A. Gottsfield, D. Gillette, V. Bellifemine, E. Strother, R. Carier, and D.A. Fredrickson. 2007. Punctuated Change in the San Francisco Bay Area. In California Prehistory: Colonization, Culture, and Complexity, edited by T.L. Jones and K.A. Klar, pp. 99-124. AltaMira Press, Lanham, MD.

Pilloud, M.A. 2006. The Impact of the Medieval Climatic Anomaly in Prehistoric California: A Case Study from Canyon Oaks, CA-ALA-613/H. Journal of California and Great Basin Anthropology 26:57-69.

Pilloud, M.A., A.W. Schwitalla, and T.L. Jones. 2014. The Bioarchaeological Record of Craniofacial Trauma in Central California. In Violence and Warfare Among Hunter-Gatherers, edited by M.W. Allen and T.L. Jones, pp. 257272. Left Coast Press, Walnut Creek, California.

Raab, M.L. and D.O. Larson. 1997. Medieval Climatic Anomaly and Punctuated Cultural Evolution in Coastal Southern California. American Antiquity 62:319-36.

Schniter, E., M. Gurven, H.S. Kaplan, N.T. Wilcox, and P.L. Hooper. 2015. Skill ontogeny among Tsimane forager-horticulturalists. American Journal of Physical Anthropology 158:3-18.

Schoeninger MJ. 1985. Trophic effects on ${ }^{15} \mathrm{~N} /{ }^{14} \mathrm{~N}$ and ${ }^{13} \mathrm{C} /{ }^{12} \mathrm{C}$ ratios in human bone collagen and strontium levels in bone mineral. Journal of Human Evolution 14:515-525.

Schoeninger, M.J. 2009. Stable isotope evidence for the adoption of maize agriculture. Current Anthropology 50:633-640.

Schoeninger, M.J. and M.J. DeNiro. 1984. Nitrogen and carbon isotopic composition of bone collagen from marine and terrestrial animals. Geochim Cosmochim Acta 48:625-639.

Schwarcz HP. 2000. Some biochemical aspects of carbon isotopic paleodiet studies. In: Ambrose SH, Katzenberg MA, editors. Biogeochemical approaches to paleodietary analysis. New York: Kluwer Academic. p 189-209. 
Schwarcz, H. P. and M. J. Schoeninger. 1991. Stable Isotope Analyses in Human Nutritional Ecology. Yearbook of Physical Anthropology 34:283-321.

Schwitalla, A.W. 2013. Global Warming in California: A Lesson from the Medieval Climatic Anomaly. Center for Archaeological Research at Davis, volume 17, University of California, Davis.

Schwitalla, A.W. and T.L. Jones. 2012. A Land of Many Seasons: Bioarchaeology and the Medieval Climatic Anomaly Hypothesis in Central California. In Contemporar Issues in California Archaeology, edited by T.L. Jones and J.E. Perry, pp. 93-114. Left Coast Press, Walnut Creek, California.

Schwitalla, A.W., T.L. Jones, M.A. Pilloud, B.F. Codding, and R.S. Wiberg. 2014. Violence among Foragers: The Bioarchaeological Record from Central California. Journal of Anthropological Archaeology 33:66-83.

Sellen, D.W. 2006. Lactation, Complementary Feeding, and Human Life History. In The Evolution of Human Life History. K. Hawkes and R. Paine, eds. Pp. 155-196.

Smith, E.A., R. Bliege Bird, and D.W. Bird. 2003. The benefits of costly signaling: Meriam turtle hunters and spearfishers. Behavioral Ecology 14:116-126.

Stine, S. 1994. Extreme and persistent drought in California and Patagonia during mediaeval time. Nature 369(6481):546-549.

Tieszen LL, Fagre T. 1993. Effect of diet quality and composition on the isotopic composition of respiratory CO2, bone collagen, bioapatite, and soft tissues. In: Lambert JB, Grupe G, editors. Prehistoric human bone: archaeology at the molecular level. New York: Springer-Verlag. p 121-155.

Tucker, B. and A.G. Young. 2005. Growing Up Mikea. In Hunter-Gatherer Childhoods, eds. B.S. Hewlett and M.E. Lamb. AldineTransaction, New Brunswick, New Jersey.

Turnbull, C.M. 1962. The forest people: A study of the Pygmies of the Congo. Simon and Schuster, New York.

White, T.D. and P.A. Folkens. 2005. The Human Bone Manual. Academic Press, Boston.

Wohlgemuth, E. 1996. Resource Intensification in Prehistoric Central California: Evidence from Archaeobotanical Data. Journal of California and Great Basin Anthropology 18:81-103.

Wohlgemuth, E. 2004. The Course of Plant Food Intensification in Native Central California. Unpublished Ph.D. dissertation, Department of Anthropology, University of California, Davis. 


$\begin{array}{rllcccc}\text { Burial } & \text { Sex } & \begin{array}{c}\text { Age at } \\ \text { Death }\end{array} & \begin{array}{c}\text { Elements } \\ \text { Sampled }\end{array} & \begin{array}{c}\text { Conv. AMS date } \\ \text { (years BP) }\end{array} & \begin{array}{c}\text { Cal BP } \\ \text { (median) }\end{array} & \begin{array}{c}\text { Cal BP } \\ \text { (1- } \sigma \text { range) }\end{array} \\ 1 & \mathrm{~F} & 25-30 & \mathrm{RM}^{1} & 570 \pm 40 & 598 & 536-634 \\ 9 & \mathrm{~F} & 18-25 & \mathrm{RM}_{1} & 670 \pm 30 & 641 & 567-669 \\ 24 & \mathrm{M} & 35-40 & \mathrm{LM}_{1} & 1105 \pm 30 & 1010 & 970-1053 \\ 32 & \mathrm{~F} & 20-25 & \mathrm{LM}^{1} & 1180 \pm 45 & 1109 & 1057-1177 \\ 42 & \mathrm{~F} & 30-35 & \mathrm{RM}_{1} & 1970 \pm 45 & 1921 & 1877-1986 \\ 45 & \mathrm{M} & 17-20 & \mathrm{LM}^{1} & 520 \pm 45 & 540 & 511-620 \\ 59 & \text { Ind. } & 10 & \mathrm{LM}_{1} & 1110 \pm 55 & 1026 & 939-1069 \\ 69 & \mathrm{M} & 40-45 & \mathrm{LM}_{1} & 560 \pm 30 & 593 & 535-627 \\ 75 & \text { Ind. } & 13 & \mathrm{LM}^{1} & 660 \pm 50 & 616 & 561-669 \\ 97 & \mathrm{M} & 18-23 & \mathrm{LM}^{1} & 920 \pm 55 & 840 & 790-910 \\ 104 & \mathrm{M} & 25-30 & \mathrm{LM}^{1} & 1090 \pm 50 & 1005 & 939-1056 \\ 106 & \mathrm{~F} & 40-45 & \mathrm{LM}_{1} & 780 \pm 50 & 711 & 673-733 \\ 108 & \mathrm{~F} & 18-23 & \mathrm{RM}^{1} & 1040 \pm 30 & 951 & 930-964 \\ 114 & \text { Ind. } & 8 & \mathrm{RM}_{1} & 600 \pm 50 & 601 & 548-646 \\ 115 & \mathrm{M} & 35-40 & \mathrm{LM}_{1} & 690 \pm 80 & 646 & 557-692 \\ 125 & \text { Ind. } & 8 & \mathrm{LM}_{1} & 1045 \pm 65 & 962 & 913-1056 \\ 128 & \mathrm{M} & 43-48 & \mathrm{M} 1 & 1080 \pm 50 & 996 & 935-1052 \\ 134 & \text { Ind. } & 13-18 & \mathrm{M} 1_{1} & 460 \pm 30 & 513 & 502-523 \\ 136 & \text { Ind. } & 8 & \mathrm{LM}^{1} & 1470 \pm 50 & 1363 & 1310-1393 \\ 143 & \mathrm{M} & 25-30 & \mathrm{M} 1_{1} & 1500 \pm 60 & 1396 & 1315-1515 \\ 148 & \text { Ind. } & 7 & \mathrm{M} 1^{1} & 630 \pm 50 & 604 & 557-658 \\ 157 & \mathrm{~F} & 30-35 & \mathrm{RM}^{1} & 1040 \pm 30 & 951 & 930-964 \\ 165 & \text { Ind. } & 13-15 & \mathrm{M} 1^{1} & 1010 \pm 60 & 923 & 800-977 \\ 169 & \text { Ind. } & 10 & \mathrm{LM}^{1} & 540 \pm 60 & 563 & 515-632\end{array}$




\begin{tabular}{|c|c|c|c|c|c|}
\hline Burial & Sex & $\begin{array}{l}\text { Duration of Exclusive } \\
\text { Breastfeeding } \\
\text { (months) }\end{array}$ & $\begin{array}{l}\text { Duration of } \\
\text { Weaning } \\
\text { Period }\end{array}$ & $\begin{array}{l}\text { Age at } \\
\text { Complete } \\
\text { Weaning }\end{array}$ & $\begin{array}{l}\delta^{15} \mathrm{~N} \text { Post- } \\
\text { Weaning (\%o) }\end{array}$ \\
\hline 1 & $\mathrm{~F}$ & 30 & 18 & 48 & 8.7 \\
\hline 9 & $\mathrm{~F}$ & 12 & 14 & 26 & 7.3 \\
\hline 24 & $M$ & 16 & 14 & 30 & 8.1 \\
\hline 32 & $\mathrm{~F}$ & 10 & 14 & 24 & 8.2 \\
\hline 42 & $\mathrm{~F}$ & 10 & 7 & 17 & 8.7 \\
\hline 45 & M & 11 & 28 & 39 & 7.7 \\
\hline 59 & Ind. & 14 & 14 & 28 & 9.4 \\
\hline 69 & $\mathrm{M}$ & 5 & 25 & 30 & 7.6 \\
\hline 75 & Ind. & 5 & 18 & 23 & 8.7 \\
\hline 97 & $\mathrm{M}$ & 12 & 18 & 30 & 8.6 \\
\hline 104 & $M$ & 10 & 16 & 26 & 7.4 \\
\hline 106 & $\mathrm{~F}$ & 10 & 16 & 26 & 7.9 \\
\hline 108 & $\mathrm{~F}$ & 5 & 28 & 33 & 6.8 \\
\hline 114 & Ind. & 9 & 11 & 20 & 7.7 \\
\hline 115 & $\mathrm{M}$ & 3 & 5 & 8 & 6.3 \\
\hline 125 & Ind. & 9 & 21 & 30 & 6.9 \\
\hline 128 & $\mathrm{M}$ & inconclusive & - & - & - \\
\hline 134 & Ind. & 12 & 18 & 30 & 8.2 \\
\hline 136 & Ind. & 6 & 14 & 20 & 7.8 \\
\hline 143 & $\mathrm{M}$ & 12 & 18 & 30 & 8.5 \\
\hline 148 & Ind. & 18 & 7 & 25 & 9.2 \\
\hline 157 & $\mathrm{~F}$ & 28 & 25 & 53 & 8 \\
\hline 165 & Ind. & inconclusive & - & - & - \\
\hline 169 & Ind. & 8 & 15 & 23 & 8.6 \\
\hline \multirow[t]{3}{*}{ Overall } & mean & 11.6 & 16.5 & 28 & 8 \\
\hline & mode & 12 & 17.7 & 30 & 8.7 \\
\hline & $\sigma$ & 6.7 & 6.2 & 9.6 & 0.8 \\
\hline
\end{tabular}


Figure 1

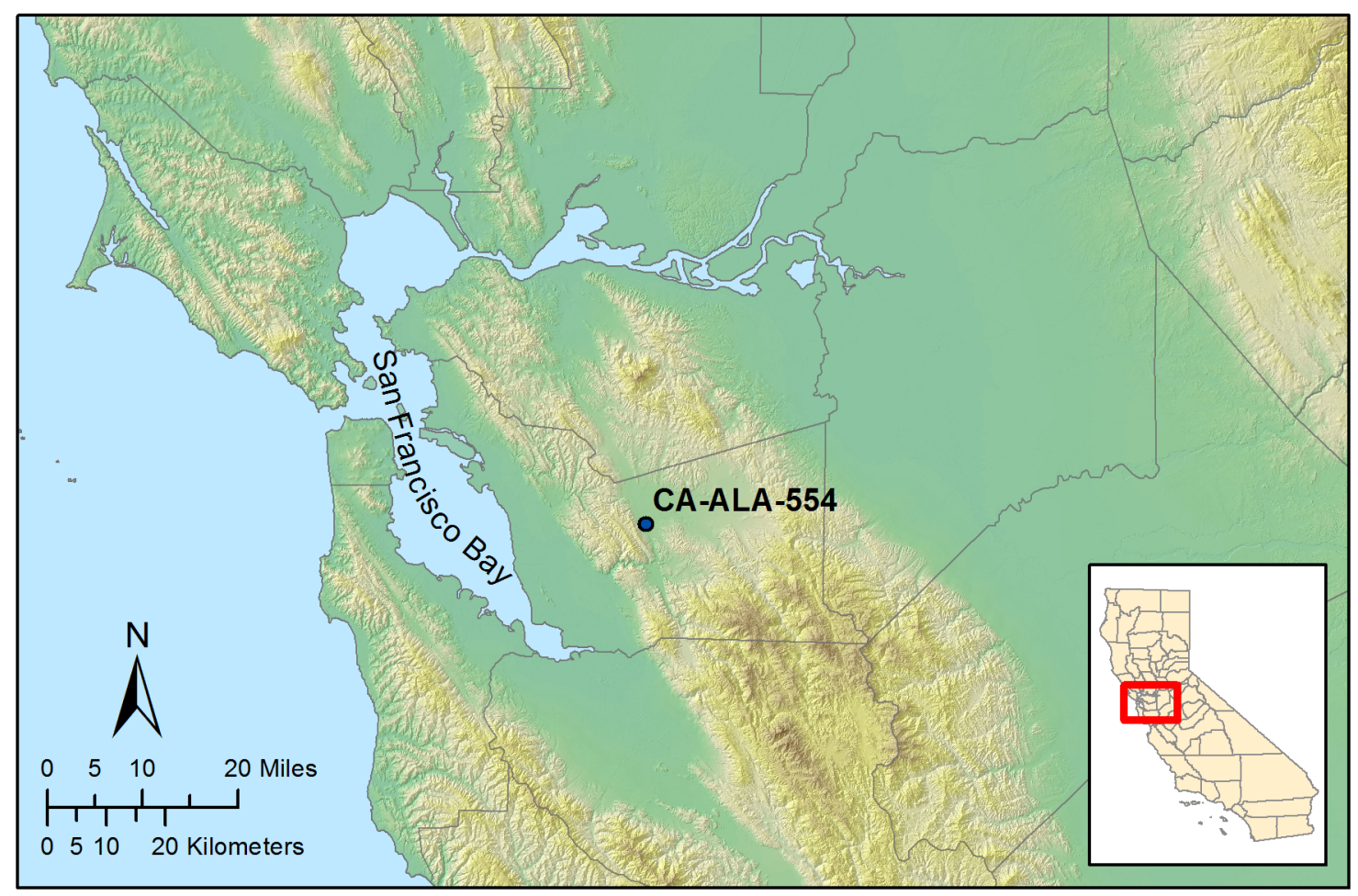


Figure 3

\section{California Resources}

\section{Collagen Isotopic Space}

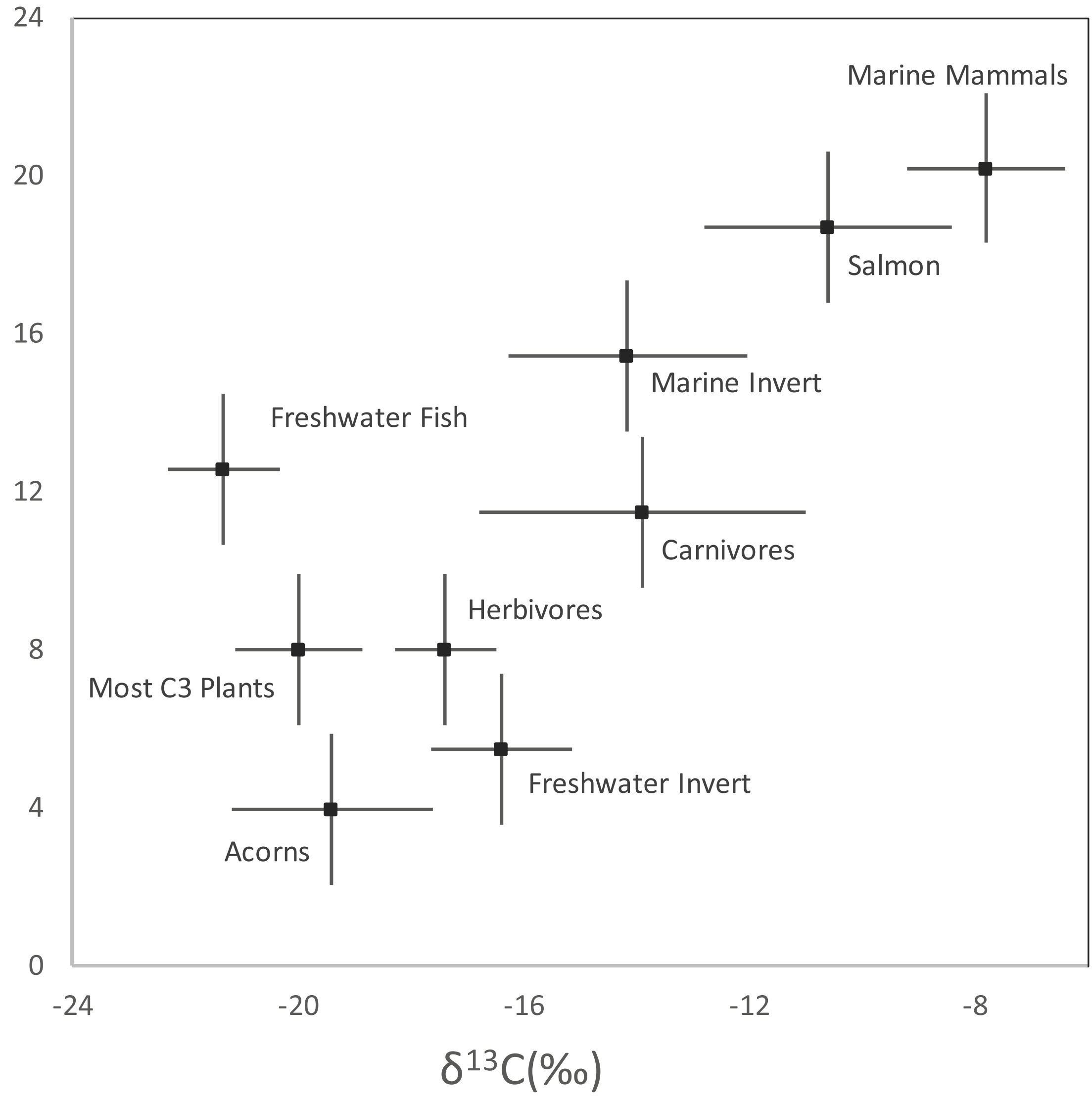


Figure 4
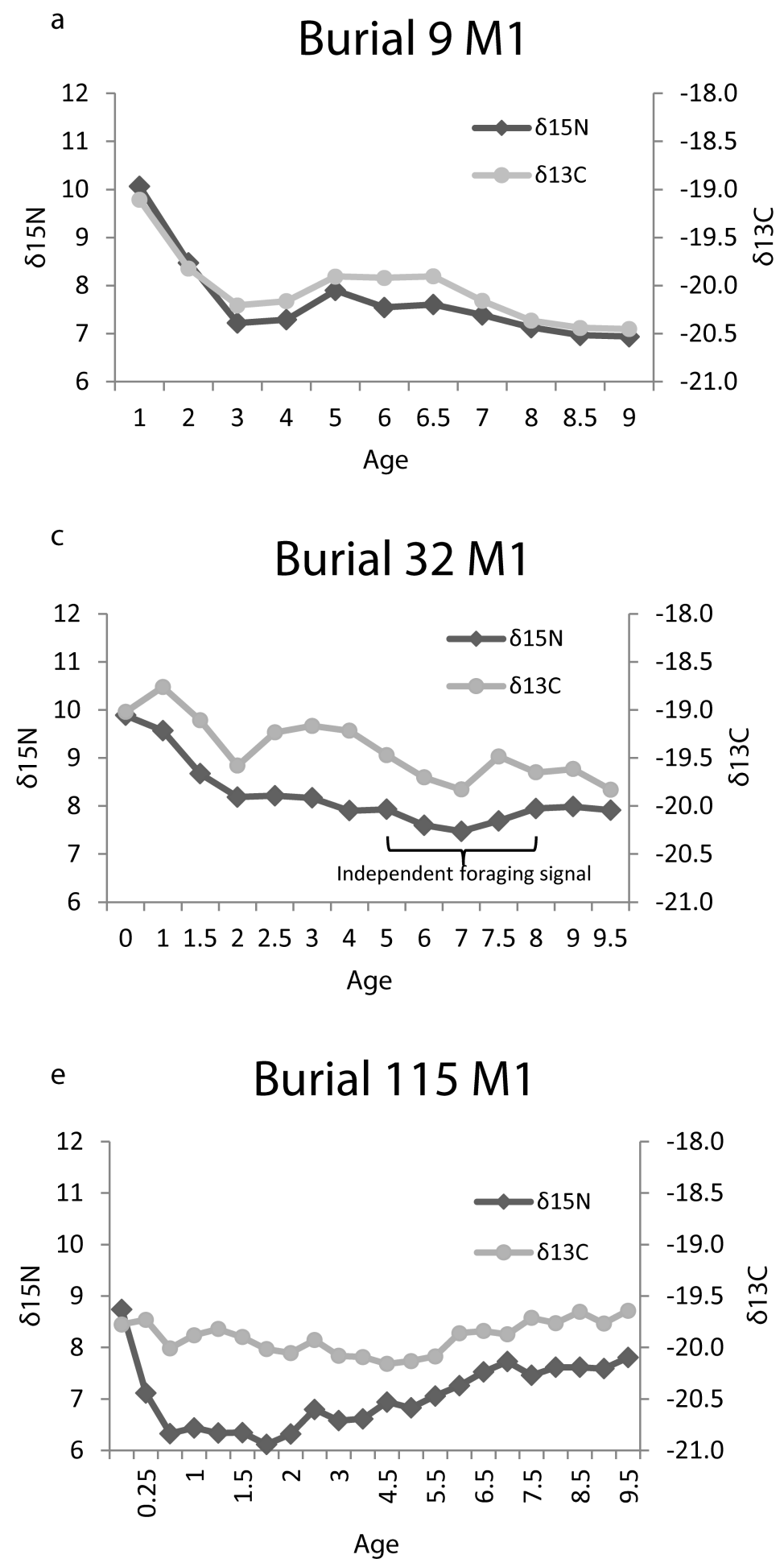

b

Burial 24 M1

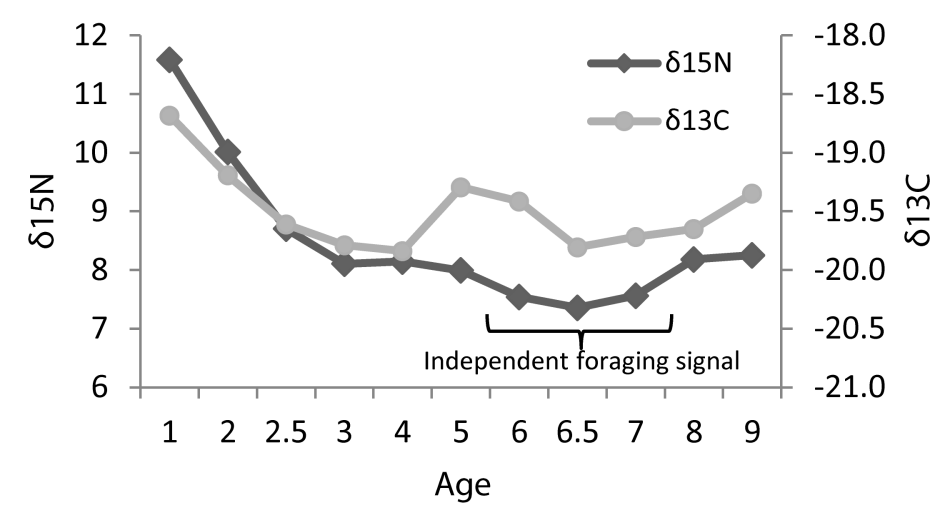

d $\quad$ Burial 104 M1
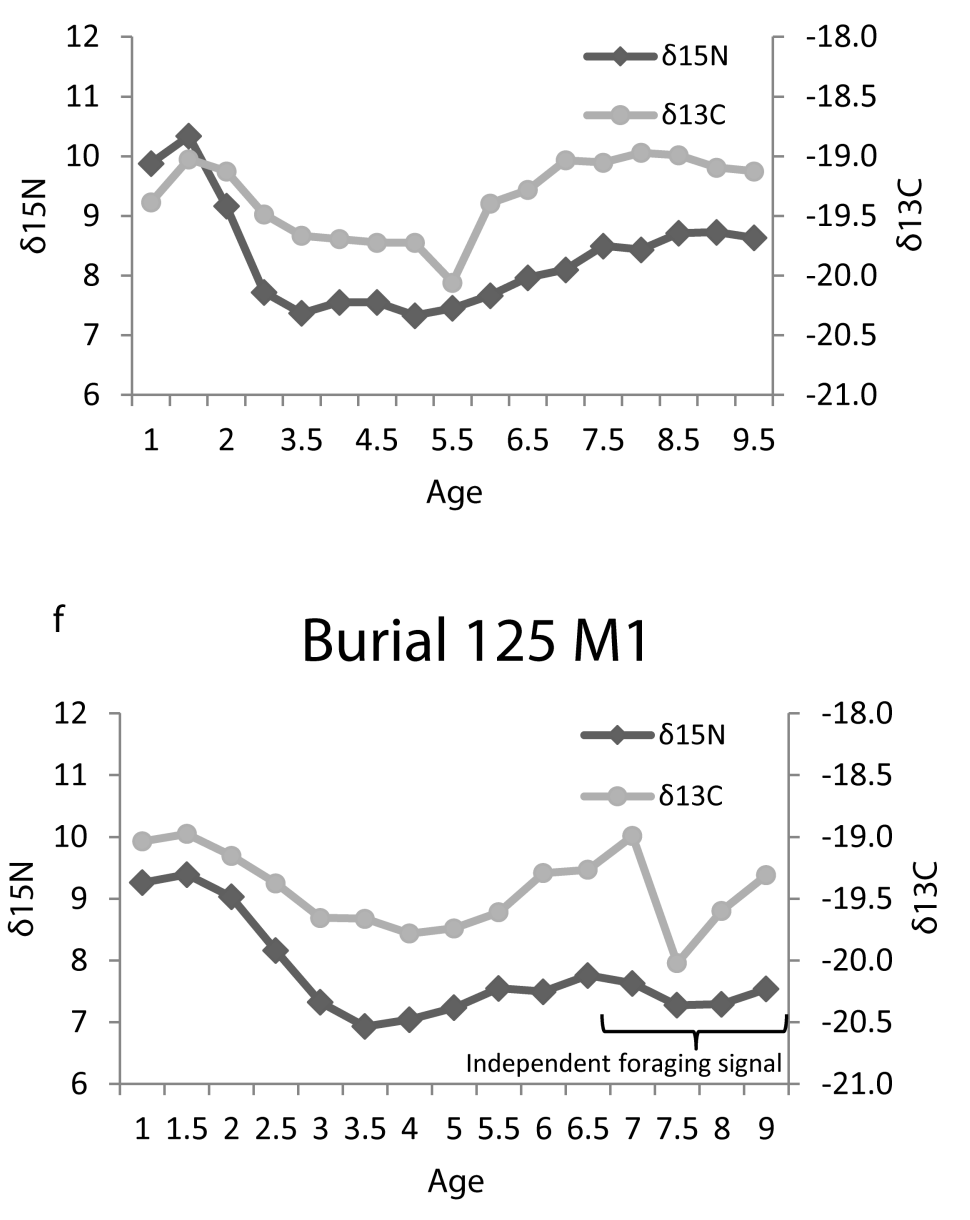
Figure 5

\section{Adult versus Weanling Diet}

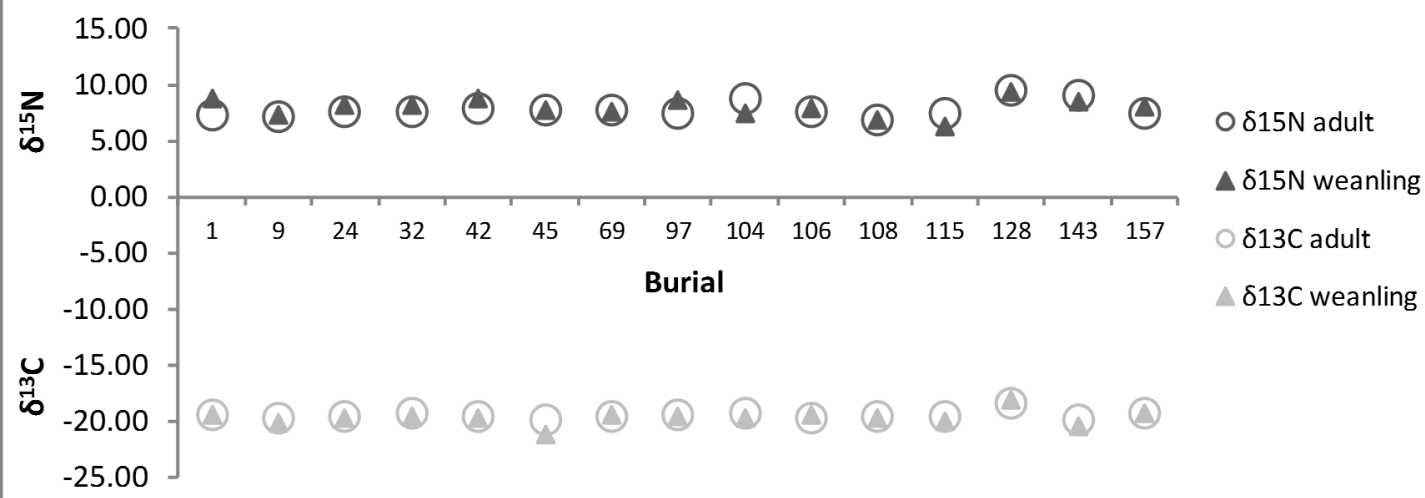




\section{Figure 6}

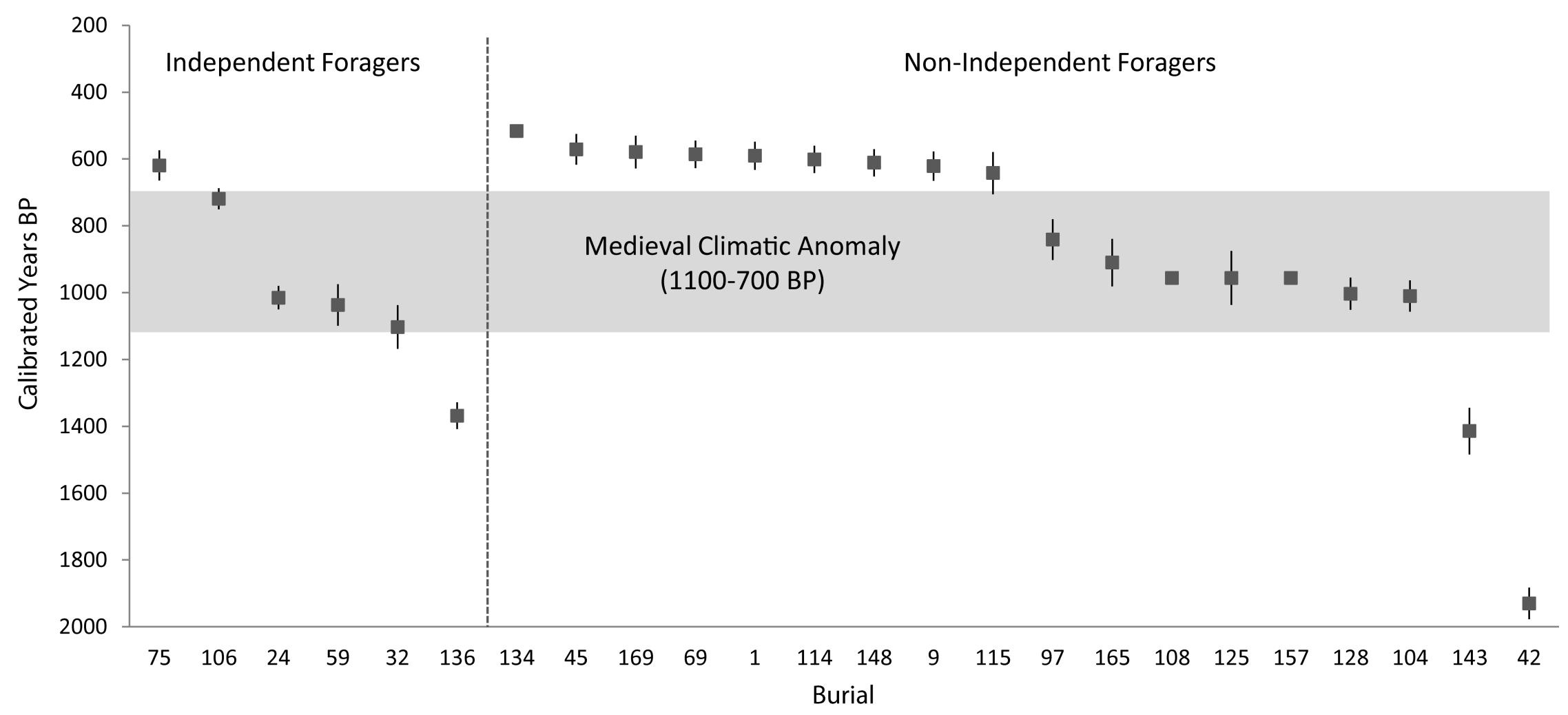

